\title{
DÍA INTERNACIONAL DE LOS BASTONES BLANCOS Y LA ASOCIACIÓN AL NOOR EN EL SULTANATO DE OMÁN
}

\author{
NOGUERA $\mathbf{J J}^{1}$
}

El Sultanato de Omán está situado en el extremo suroriental de la península arábiga. Al norte, con el golfo de Omán, al este y al sur extiende sus costas sobre el mar Arábigo; su porción suroccidental hace frontera con el Yemen, y por el oeste limita con Arabia Saudí y con los Emiratos Árabes Unidos en cuyo territorio posee un pequeño enclave, Mahda, y la península de Musandam la cual, componiendo el estrecho de Ormuz con las costas de Irán, separa el golfo Pérsico del de Omán. La capital de este sultanato es Mascate, su extensión es algo superior al $60 \%$ de la de España $\left(309.500 \mathrm{~km}^{2}\right)$ y su población (2006) es de 3.102.229 habitantes.

El sello que hoy publicamos fue emitido por los servicios postales del Sultanato de Omán el 15 de octubre de 2004 con ocasión del Día Internacional del Bastón Blanco (The International White Cane day), fecha en la que se conmemora la creación en $1930 \mathrm{del}$ bastón blanco con una banda roja en su extremo como ayuda de seguridad para los ciegos - atribuida, en los Estados Unidos, a George A. Bonham, miembro del Lions Club de Peoria, Illinois.

La asociación Al Noor para la ayuda a los ciegos, también citada en este sello, es una organización humanitaria no gubernamental fundada en 1997 en el Sultanato de Omán donde hay alrededor de 17.000 personas con graves deficiencias visuales.

Sobre el sello está impreso un texto mediante el sistema Braille.

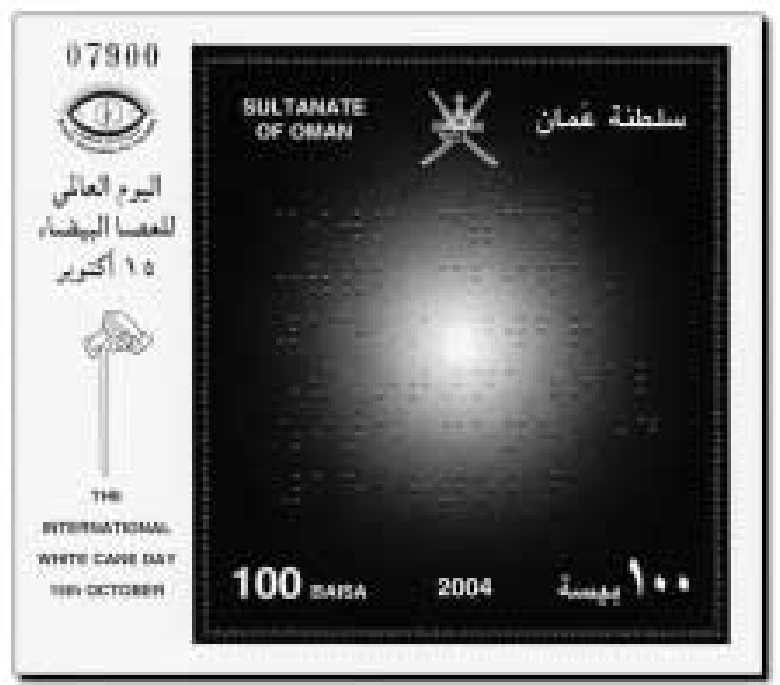

Fig. 1: Omán, 2004 / Yvert: HB 36. 